\title{
Organic seeds of the future: simple material?
}

\author{
Dominique Desclaux
}

Received: 1 April 2020 /Accepted: 27 April 2020 /Published online: 13May 2020

(C) The Author(s) 2020

\begin{abstract}
The day where seeds were considered "material" in legal text was a decisive moment. At the European level, that was December 1, 1961, when the international convention for the protection of new varieties of plants (UPOV) was adopted by the diplomatic conference. This paper relates the semantic evolution in French and European regulations concerning seeds. Using the term "material" to define a seed sounds as an oxymoron and especially for the organic sector that highlights the concept of life integrity of plants. Semantic drifts and technical drifts are close. To consider seeds as simple material allows everybody to manipulate them, to modify them, to degrade them, to repair them, to edit them, to market them, and to patent them. The drift in regulatory texts is not insignificant; it reflects the thought of a society but can also have a sustainable impact on this thought. Therefore, it seems urgent to raise the question: What seeds do we want in the future? Patented seeds, edited seeds, certified seeds, farm seeds, peasant seeds, participatory seeds? It's time to decide! And time to precise the words in legal texts.
\end{abstract}

Keywords Legal text - Seed regulation · Plant breeding . Participatory Varieties

D. Desclaux $(\bowtie)$

INRAE, UE1098, Domaine de Melgueil, 34130, Mauguio, France e-mail: dominique.desclaux@inrae.fr

\section{A growing number of seed regulations}

Seed, as the first link in the food chain, is at the heart of strategic issues and particularly subject to numerous regulations. France, inspired by the Czechoslovak law ${ }^{1}$, was one of the first countries to establish by decree, in 1922, a register of selected plants and to set up a seed control committee. Since then, the number of French laws, decrees, and regulations concerning seeds has increased exponentially (Fig. 1).

\section{Semantic shift from "seed" to "material"}

The day where seeds or plants were considered "material" in legal text was a decisive moment.

This day was December 1, 1961, when the international convention for the protection of new varieties of plants (UPOV) was adopted by the diplomatic conference. In this first convention, the term material is used 11 times: 5 in the article 5 concerning rights protected and scope of protection "The effect of the right granted to the breeder of a new plant variety $[\ldots]$ is that his prior authorization shall be required for the production, for purposes of commercial marketing, of the reproductive or vegetative propagating material, as such, of the new variety, and for the offering for sale or marketing of such material. Vegetative propagating material shall be deemed to include whole plants. The breeder's right shall extend to ornamental plants or

\footnotetext{
${ }^{1}$ Law of March 17,1921 , on the recognition of the originality of types,
} seeds and plants, and the examination of horticultural subjects 
Fig. 1 Time evolution of the number of French laws, decrees and arrêtés concerning seeds

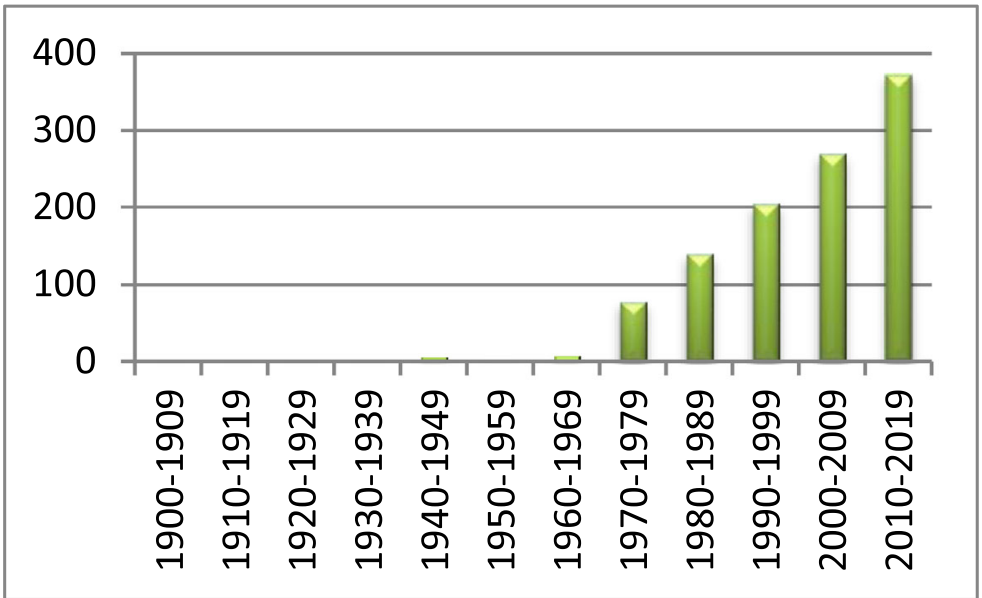

parts thereof normally marketed for purposes other than propagation when they are used commercially as propagating material in the production of ornamental plants or cut flowers"; one time in article 7 " $[$...] the competent authorities of each country may require the breeder [..] to furnish all the necessary information, documents, propagating material or seeds"; once in article 8: "concerning the production and marketing of seeds and propagating material'; 2 times both in article 8 and in article 10: "reproductive or propagating material', once in article 12 "documents and material required by the laws", once in article 13 "reproductive or vegetative propagating material", once in article 14 "certification and marketing of seeds and propagating material".

In this convention, the term material is mainly affixed to the term "propagating." We may observe that in 3 articles (art7, 8 and 14) the word "seed" is used independently of the term "propagating material."

In the UPOV convention revised on March 19, 1991, the term material is found 27 times, and in 8 cases it is affixed to the term "harvested." Article 14 (Scope of the Breeder's Right) gives the definition: "harvested material, including entire plants and parts of plants" and Article 16 (Exhaustion of the Breeder's Right) adds "material means, in relation to a variety, (i) propagating material of any kind, (ii) harvested material, including entire plants and parts of plants, and (iii) any product made directly from the harvested material."

The word "seed" is no more present in this revised convention and was therefore included in the term "material."

In the French legal texts, it seems that the word matériel (material) appears for the first time in the decree no. 71-828 of September 16, 1971, related to the grapevines planting and production, circulation and distribution of vegetative propagation material. In this text, they are considered propagation material: "Rooted vine plants, graft-welded, potted plants, cardboard plants, shoots and cuttings." This text derived from those of the council directive of April 9, 1968, on the marketing of material for the vegetative propagation of the vine (68/193/EEC) in which the word material is used 113 times!

Today, nobody pays attention to the use of this term. It has completely entered the current vocabulary to name a seed, a vegetal, or a part and is used by all the actors of the agricultural sector. Even in the scientific literature, the description of the plant species and varieties is ranked in the "material and methods" section.

But is it a meaningless or an innocuous term?

\section{What terms were used in the past?}

Lists of precise words were used, such as: "plants, seeds, bulbs, tubers, cuttings or grafts", "bulbs, onions , flower cuttings, seeds, cuttings, grafts, plants, scions and fruit trees". 3

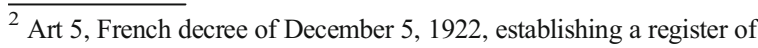
selected plants and establishing a seed control committee, and law of October 11, 1941, on the organization of the market for seeds (semences), seeds (graines), and seedlings

${ }^{3}$ arrêté du sept 7, 1952, et arrêté du juillet 28, 1954: commerce des boutures, greffons, plants, scions et arbres fruitiers et du janvier 7 , 1962: commerce des graines, greffons, boutures ou plants d'essence forestières
} 


\section{What about the organic regulation?}

Throughout the European Union, regulation (EC) No $834 / 2007$ specified all the rules to be followed concerning the production, processing, distribution, import, control, and labelling of organic products. In this text, 35 occurrences of the word material are found, essentially "feed material" and "vegetative propagating material".

This regulation has been repealed by the regulation (EU) 2018/848 of the European parliament and of the council of 30 may 2018 on organic production and labelling of organic products. In this new one, there are 138 occurrences of the word material. It is often present as "plant reproductive material" (47 times), "feed material" (29) but also newly as "organic heterogeneous material" (17), "plant genetic material" (2), or "parental material" (2).

According to the article 3-18: "organic heterogeneous material means a plant grouping within a single botanical taxon of the lowest known rank which: (a) presents common phenotypic characteristics; (b) is characterized by a high level of genetic and phenotypic diversity between individual reproductive units, so that plant grouping is represented by the material as a whole, and not by a small number of units; (c) is not a variety within the meaning of Article 5 of Council Regulation (EC) $\mathrm{N}^{\circ} 2100 / 94$; (d) is not a mixture of varieties; and (e) has been produced in accordance with this Regulation".

This regulation 2018/848 will come into force in January 2021.

\section{What does this semantic drift mean?}

Used as an adjective, the word material can be opposed to the word spiritual; therefore, everything that is not of the spiritual sphere is called material. Of which act.

A short parenthesis must be open here concerning the French language case: Three terms can translate the English term material into French: matière, matériau and matériel. In the French legal texts concerning seeds, this last term was chosen. This term is most commonly defined by "the set of objects, instruments, equipment and tools used in a service, an operation; e.g.: used material; acquisition, maintenance or lack of material; bring your material; renew the material, defective or advanced material, purchase, repair, renewal, endowment, investment in material, distribution, pile up" ${ }^{4}$.

Therefore, to consider seeds as material means to allow oneself to manipulate them, to degrade them, to repair them, to edit them, to market them, and to patent them.

It's as if no longer talking about plants, seeds, cuttings, roots, etc., but talking about materials equals to denying their belonging to the general classification of living beings! The same is true for animal seeds for which the expression "animal reproductive material" is used in various European regulatory texts. ${ }^{5}$

The drift in regulatory texts is not insignificant. Regulatory texts record the spirit of a society at a given time. They represent a good illustration of how mentalities are changing. But the consignation in a text of law tends to inscribe this spirit in marble, because it makes reference.

At the beginning, the word material did not include seeds since the regulatory texts maintained the 2 terms; today this word material covers not only the seeds but all organs used for reproduction (tubers, cuttings, bulbs, rhizomes...), all the products of the harvest (grains, tubers, ...), and also any vegetative part of a plant as well as any product manufactured directly from the product of the harvest (art16, UPOV).

The word material has become very encompassing and therefore polysemic. It replaces a litany of precise biological terms and has the usefulness of reductionism to limit the number of pages of legislative texts! But it has the major disadvantage of not being a harmless word. This materialization of life necessarily leads to deviations, unless it is the opposite. Semantic drifts and technicist drifts are close. We are very far from the spirit of the primitive mythologies involving seeds! Maya traditions, for instance, explained the genesis of the human thanks to the maize seeds: " the yellow ears and the white ears of corn were ground and mixed with water to obtain a paste with which we made our first father, our first mother. It only took an instant. Men and women were already standing and chatting with each other.» ${ }^{6}$

Even IFOAM introduces the word material in its position paper on seeds! ("The Use of Organic Seed

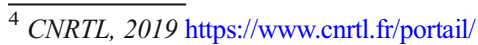

5 e.g., directive 98/44/EC of the European parliament and of the council of July 6, 1998, on the legal protection of biotechnological inventions

${ }^{6}$ Dalongeville,A. 2007. Pédagogie pratique, situations-problèmes pour enseigner l'histoire au cycle 3. Hachette éducation.256 pp.
} 
and Plant Propagation Material in Organic Agriculture, approved by the World Board in August 2011"). However, in accordance with the 4 principles of organic agriculture, Health, Ecology, Fairness and Care, it was agreed that breeding methods must respect the "life integrity, planttypic integrity, phenotypic integrity and genotypic integrity. Techniques at whole plant or crop level are in line with the principles of organic farming, respecting the self-reproductive ability and the reproductive barriers. In vitro techniques and techniques at DNA level are not compatible with the integrity of plants, except for the use of DNA markers.[..] By introducing the concept of integrity of plants, the organic sector challenges the plant breeders to develop additional and new approaches for organic plant breeding and propagation". 7

\section{Conclusion}

What will the organic seeds of the future look like if we continue to consider them as simple material? Patented seeds, edited seeds, certified seeds, farm seeds, peasant seeds, participatory seeds?

It is finally the relationship to the living that is questioned. Between an ecocentric vision that prohibits any action on non-human life, and an anthropocentric vision that justifies the exploitation of any resource for the well-being of man, an alternative path must be considered. This path should be that of a dematerialization society in which each living being respects the integrity of others.

Would GMO and NPBT have occurred if the seed had not been considered as material?

Authors' contributions Not applicable.

Availability of data and material Open sources.

Code availability Not applicable.

Open Access This article is licensed under a Creative Commons Attribution 4.0 International License, which permits use, sharing, adaptation, distribution and reproduction in any medium or format, as long as you give appropriate credit to the original author(s) and the source, provide a link to the Creative Commons licence, and indicate if changes were made. The images or other third party material in this article are included in the article's Creative Commons licence, unless indicated otherwise in a credit line to the material. If material is not included in the article's Creative Commons licence and your intended use is not permitted by statutory regulation or exceeds the permitted use, you will need to obtain permission directly from the copyright holder. To view a copy of this licence, visit http://creativecommons.org/licenses/by/4.0/.

Publisher's note Springer Nature remains neutral with regard to jurisdictional claims in published maps and institutional affiliations.

\footnotetext{
${ }_{7}^{7}$ Lammerts van Bueren, E. (2002) Organic plant breeding and propagation" Thesis, Wageningen University, The Netherlands/Louis Bolk Instituut.
} 